\title{
Research for Motivating Mechanism of City Household Garbage Resources
}

\author{
Yaping Chen ${ }^{\mathrm{a}}$, Junqing Zhong ${ }^{\mathrm{b}}$, Ting Tian ${ }^{\mathrm{c}}$, Sainan Wang ${ }^{\mathrm{d}}$ \\ Shanghai University of Engineering Science, Shanghai 201620, China \\ a yaping6688@126.com, ${ }^{\mathrm{b}}$ karlzhongjq@126.com, ${ }^{\mathrm{c}}$ ttingdream@163.com, ${ }^{\mathrm{d}}$ 877527533@qq.com
}

\begin{abstract}
Environmental issues are highly concerned today, in which household garbage resource utilization is most important. This paper analyzes the current situation of household garbage resource and existing problem from the point of view of reverse logistics. This paper proposes the government's stimulus measures of production enterprises, the public, solid waste industry, so as to promote the development of domestic solid waste treatment industry in China.
\end{abstract}

Keywords-household garbage; resource utilization; incentive mechanism.

\section{Current Situations And Problems For City HOUSEHOLd GARBAGE RECYClE}

According to Shanghai statistical yearbook, Shanghai household garbage is 6.22 million tons in 2005, and 7.35 million tons in 2013, the average daily amount is 19,000 tons. Compared with 2005, the total garbage amount in 2013 increases 18.2\%, average annual increases 2.3\%. There is much garbage in the city, including paper, fiber, metal, glass and the other that can be recycled. Some solid waste can be burn to give out heat for generating electricity and supplying heat. Garbage that contains high organic substance can be used to generate electricity or supply heat by fermentation and centralized recovery of biogas. Though governments at all levels have already put forward the requirements for quickening the establishment of entire collector disposal system and for achieving of reducing, recycling and refusing disposal for household garbage. So far, still there are some problems existing in the recycling management of household garbage as the following:

A. Institutional constraints in carrying out the incentive mechanism for household garbage recycle

Construction of laws and regulations is the important foundation for the development of renewable resources industries, so far, a series of provisions in terms with household garbage have been enacted by the nation, but slackness still exists in law enforcement, and lack of certain motivating and constraining mechanism. Seen from the perspective of application of funds, a series of industry supportive policies should be made and be enacted, under the market-oriented economy conditions, economic lever should be used to arouse the enthusiasm of the whole society all walks of life to participate the environmental protection industry.
B. The residents' lack of relatively knowledge and information, participation degree is limited

Compared with developed countries, there is a huge difference for our citizens' awareness and participation on the respect of waste sorting recycle. Public ecological civilization consciousness presents a state of "high recognition, low awareness and insufficient practice”, governments' research of public ecological civilization awareness lacks of unified, normative, and instructional indicator system, which makes the consciousness of ecological civilization assessment lagged.

C. Bewilderment of funds, technique, talents makes it hard for city household solid waste recycling dispose enterprises to survive.

Government is positively encouraging the recycle of city household garbage and the research and development of the relating technique and facilities. Nevertheless, on the respect of implementing the funds is not the best and the lack of comprehensive development of new technology and new process, which causes serious secondary pollution and to some extend affects technological extension and industrial development of enterprises that unitize solid waste recycling dispose.

\section{Government supervising degree and extent}

Though government enacts relating policies for environmental protection, but the disjoint between action and thoughts still exists. Besides, the low consciousness of the public, the insufficient supervising degree is also an important factor, which performs mainly as hard to dispose the operational irregularities, information asymmetry exists between supervising apartments, expenditure for supervising work is insufficient and the supervising professionalization is not high. Secondly, there are shortcomings in the policies, the provisions and the standard legal norm and causes the insufficient supervising gist; thirdly, rights and obligations of the supervising organization is not certain, the combination of the force is not strong, and the whole city supervising system has not been built.

\section{COST AND BENEFIT ANALYSIS BASED ON REVERSE LOGISTICS}

As urban household garbage recycling development is with huge external economy, recycling enterprises and 
individuals get less profit than social benefit, which brings "market failure". Reverse logistics refers the process of regain the values from the material waste during production process, the final remaining wrappage of the product sales, wasted products, defective product and the returned goods or makes them to be properly disposed so as to reduce environmental pollution and from the ending place to the original place. It is an important part of enterprises logistics system. Reverse logistics brings huge economic profits and at same time consumes the cost of the enterprises. Just for the external economic efficiency of reverse logistics, so cost benefit analysis is needed for reverse logistics.

Reverse logistics cost refers to monetary form of expenditure and material consumption that produced during the process that circulating or manufacturing enterprises regain values from the material waste during production process, the final remaining wrappage of the product sales, wasted products, defective product and the returned goods or makes them to be properly disposed so as to reduce environmental pollution.

The initial direct reason for enterprises to carry out reverse logistics not only is the constraint of environmental protection, law and energy conservation aspects, but also includes the driven by economic profits, the implementing of reverse logistics will bring a good economic profits , so that enterprises have enthusiasm and initiative to carry out reverse logistics. Because implementing of reverse logistics can save the cost for purchasing components and raw material, and manufacturing expenses. The used components and material through processing and disposing can be re-sold to get sales revenue and can reduce the discharge amount of contaminant, so that to lower the sewage treatment fee and reduce the expenditure for environmental protection, the final waste can be buried and burned to achieve energy recycle. These are the economic profits of reverse logistics.

Through the above analysis, cost benefit calculating model for reverse logistics is as the following:

Benefits of reverse logistics $=$ (Recreating income of reverse logistics+ Income of renewable materials + Benefit of collecting energy from the burned waste+ Benefit of environmental protection ) - (Collection cost of reverse logistics + Testing costs + Disassembly cost + Components remanufacturing cost + Renewable materials cost + Landfill costs + Incineration costs ), that is: $R_{R L}=\left(R_{M}+R_{P}+R_{I}+\right.$ $\left.R_{E}\right)-\left(C_{C}+C_{T}+C_{D}+C_{M}+C_{P}+C_{I}+C_{L}\right)$

Costs and benefits model of reverse logistics can assist enterprises to judge accurately about their costs and benefits in implementing reverse logistics, to strengthen the accuracy of the enterprise's decision, and to improve economic and social benefit of reverse logistics system operation more effectively.

\section{MOTIVATING MECHANISM FOR URBAN HOUSEHOLD GARBAGE RECYCLE}

Through the analysis of reverse logistics cost, during the process of urban household garbage recycle, some costs need to be compensated by the operation of market mechanism and some other costs need government to employ positive measures to coordinate properly. Therefore, motivating mechanism need to be built for urban household garbage recycle. In this paper, we put forward a motivating mechanism called "a body with three wings", "three wings" refers to "garbage charging mechanism, ecological compensation mechanism, market competitive mechanism", "one body" refers to "supervision and evaluation mechanism". Through the "three wings" mechanism that government, enterprises, and citizens seek common points while reserving difference, we use this "one body" mechanism of supervision and evaluation to ensure every policy to be implemented and improved.

\section{A. Garbage charging mechanism}

The charging for household garbage has certain motivating effect, and based on extruding "polluters pay principle" that is helpful to motivate the citizens' starting to reduce the garbage in categories. At the same time, give corresponding compensation to enterprises and individuals with excellent performance is feasible at present stage. Garbage charging refers to: Firstly, charging for enterprises and public institutions, and build the "established producer responsibility (EPR)". Secondly, charging for individual citizen. Through foreign experiences and comparison of charging ways between some domestic provinces, combined with the comparison of advantages and disadvantages between different charging ways (table 1), we concluded that implementing scheme of "charging corresponding with water + charging according to amount" could take advantage of a relatively perfect platform. The platform has the advantages of wide coverage, easy and simple operation, and low charging cost, as well as convenient for people to pay.

TABLE I. WAYS OF GARBAGE CHARGING

\begin{tabular}{|c|c|c|}
\hline Way of charging & Advantage & disadvantage \\
\hline $\begin{array}{l}\text { Fixed amount (by } \\
\text { population) }\end{array}$ & $\begin{array}{l}\text { Simple, extensively } \\
\text { Covered, low cost }\end{array}$ & $\begin{array}{l}\text { Little effect to } \\
\text { garbage reduction }\end{array}$ \\
\hline $\begin{array}{l}\text { Charge by volume } \\
\text { (by weight) }\end{array}$ & $\begin{array}{l}\text { Good for garbage } \\
\text { classification, } \\
\text { garbage reduction }\end{array}$ & $\begin{array}{l}\text { Need to supply } \\
\text { uniform bag and } \\
\text { co-operation of } \\
\text { residents, high cost }\end{array}$ \\
\hline $\begin{array}{l}\text { According to water } \\
\text { usage }\end{array}$ & $\begin{array}{l}\text { Extensively covered, } \\
\text { easy operation, low } \\
\text { cost, convenient for } \\
\text { residents payment }\end{array}$ & $\begin{array}{l}\text { Need to reset the } \\
\text { charging system 、 } \\
\text { affect water charge } \\
\text { collection }\end{array}$ \\
\hline
\end{tabular}

\section{B. Ecological compensation mechanism}

Deepen the reform of price and tax for recycling products, and it is extremely urgent to establish resource reimbursable usage system and ecological compensation system, which reflect supply and demand of the market, and the resource scarcity, as well as show the ecological value and intergenerational compensation. Establish and implement ecological compensation mechanism to compensate the city household garbage recycling enterprises on aspects of funds, materials, technology and so on, which to some extent relieve the externality of 
environmental protection. For the standard accounting of ecological compensation, we comprehensively applies methods of value-loss evaluation method of ecological system's service function, costs method of ecological recovery and coefficient method at developing stage that combines Engel coefficient and Peel growth curve model together to establish the standard accounting system for ecological compensation.

\section{Market competitive mechanism}

In the process of household garbage recycling dispose, competitive mechanism is introduced to improve the service quality. Department of the Environment enacts relating liberalization policy in terms of the collection of city household garbage. Divided by geographic regions, the service of collect and dispose household garbage inside the region will employ the method of bid and gradually contract to private enterprises. This method not only eases the growing financial pressure of environmental protection for the government, but also reasonably utilizes the private capital and improves the operating efficiency of social resource.

\section{Supervision and Evaluation Mechanism}

The running enterprises in western developed countries have strong consciousness of self-discipline, pay attention to public participation and social supervision, and have generally high specialization in supervision. Shanghai government needs to play well the role of "referee" and avoid playing both roles of "referee" and of "athlete" as traditional government to solve the problem of vicious circle that 'implementation without supervision, check without punishment' under traditional mechanism. Establish supervision system to fit market-oriented reform of service dispose, the design of government supervision mechanism to fit the content of supervision goals and government supervision capability to fit government supervision responsibility.

\section{CONCLUSION}

The realization for recycling disposes of household garbage not only helpful for solving city ecological environment problems caused by household garbage, but also can get part of the resource for city development and residents' life, the market development prospect is very spacious. However, recycling dispose of household garbage is a long-term developing process that needs support from economy, culture, technology and the other aspects and needs a set of complete motivating mechanism, including garbage charging mechanism, ecological compensation mechanism, market competitive mechanism and supervision and evaluation mechanism, to ensure the implementation and the improvement of policies.

\section{V.ACKNOWLEDGEMENT}

This research was supported by key project of Scientific Research \& Innovation Project under Shanghai Municipal Educational Committee (Project No.: 12ZS174), the People's Republic of China and Innovation Project of Shanghai University Students (Project No.: CS1303002) and Connotation construction projects of Shanghai University of Engineering Science (Project No.: nhky-2014-16).

\section{REFERENCES}

[1] Dales, John. Pollution, Property, and Prices [M]. Toronto, Ontario University Press. 1968.

[2] Feng Wang; Taira Hidaka; Hiroshi Tsuno; Jun Tsubota. Co-digestion of polylactide and kitchen garbage in hyperthermophilic and thermophilic continuous anaerobic process [J] Bioresource Technology,2012,Vol.112

[3] Sarah A. Moore. Garbage matters:Concepts in new geographies of waste [J]. Progress in Human Geography, 2012,Vol.36,780-799 